\title{
ZAGOSPODAROWANIE PRZESTRZENNE GMINY WIEJSKIEJ KOTLIN W ŚWIADOMOŚCI JEJ MIESZKAŃCÓW
}

\begin{abstract}
Zarys treści: Celem artykułu jest ocena wpływu wiedzy oraz doświadczenia związanego $\mathrm{z}$ tematyką planowania przestrzennego mieszkańców gminy wiejskiej Kotlin położonej w województwie wielkopolskim na postrzeganie jej stanu zagospodarowania. $\mathrm{Na}$ podstawie badań ankietowych określono znajomość opracowań planistycznych wśród mieszkańców, odczuwanie przez nich przestrzeni oraz stan ich zadowolenia z prowadzonej w gminie polityki przestrzennej.
\end{abstract}

Slowa kluczowe: zagospodarowanie przestrzenne, planowanie przestrzenne, gmina Kotlin.

\section{Wstęp}

Gospodarka przestrzenna odgrywa szczególną rolę w społeczeństwach demokratycznych, w których każdy z obywateli może mieć wpływ na kształt najbliższego otoczenia. Należy pamiętać, że wszelkie działania podejmowane w jej zakresie mają na celu przede wszystkim poprawę jakości bytu mieszkańców m.in. poprzez polepszenie funkcjonalności i estetyki środowiska życia. Pytanie o jego przyszły kształt na danym obszarze powinno być zatem kierowane bezpośrednio do społeczności lokalnej. W Polsce proces uspołeczniania procesów związanych $\mathrm{z}$ planowaniem przestrzennym jest gwarantowany ustawowo. Problem stanowi jednak aktywność mieszkańców w partycypowaniu tych działań, czego efektem jest stan zagospodarowania przestrzeni często odbiegający od oczekiwań społecznych. Innym niepokojącym zjawiskiem jest nieznajomość opracowań planistycznych i strategicznych oraz procesów kreujących kierunki rozwoju danej jednostki terytorialnej wśród mieszkańców, co rodzi błędne przekonanie, że decyzje dotyczące gospodarki przestrzennej 
podejmują wyłącznie włodarze gminy. Te i wiele innych czynników mają istotne znaczenie podczas oceny przez społeczeństwo otoczenia, w którym żyje i funkcjonuje.

Głównym celem badań było określenie wpływu poziomu wiedzy i doświadczenia mieszkańców gminy Kotlin z zakresu planowania przestrzennego na postrzeganie jej stanu zagospodarowania. Porównano zainteresowanie kierunkami rozwoju gminy wśród społeczności lokalnej ze znajomością opracowań planistycznych. W badaniach wzięto pod uwagę odpowiedzi respondentów pod kątem oceny przez nich atrakcyjności przestrzeni gminy. Na tej podstawie spróbowano odpowiedzieć na pytania w jaki sposób na odbiór otoczenia, odczuwanie przestrzeni, ocenę estetyki i akceptację pewnych procesów wpływa znajomość tematyki planowania przestrzennego przez mieszkańców oraz jaki wpływ mają inne czynniki.

Obszar badań stanowił Kotlin - gmina wiejska o powierzchni $84 \mathrm{~km}^{2}$, leżąca w powiecie jarocińskim, w południowo-wschodniej części województwa wielkopolskiego, około $80 \mathrm{~km}$ na południowy wschód od Poznania i około $40 \mathrm{~km}$ na północny zachód od Kalisza. Gminę Kotlin tworzy 12 wsi sołeckich, z których najważniejszą rolę odgrywa miejscowość Kotlin, która jest siedzibą urzędu gminy i największym ośrodkiem usługowym oraz kulturalnym. Powierzchnia Kotlina wynosi 1410 ha, co stanowi 16,8\% powierzchni całej gminy. Większość sołectw charakteryzuje się skoncentrowaną zabudową wzdłuż głównych szlaków komunikacyjnych, jednak w każdej z miejscowości istnieje również rozproszona zabudowa zagrodowa. Liczba ludności gminy Kotlin w 2013 roku wyniosła około 7300 osób. Jest to najsłabiej zaludniona gmina w powiecie jarocińskim. Gęstość zaludnienia to $87 \mathrm{osób} / \mathrm{km}^{2}$ na koniec 2013 roku, przy czym średnia gęstość zaludnienia w powiecie to prawie 122 osoby $/ \mathrm{km}^{2}$, a w województwie wielkopolskim 116 osób $/ \mathrm{km}^{2}$. Najbardziej zaludnioną miejscowością w gminie w 2013 roku był Kotlin z liczbą 3146 mieszkańców, co stanowiło prawie 43\% populacji gminy. Przez obszar omawianej jednostki terytorialnej przebiega droga krajowa $\mathrm{nr} 11$, która łączy północ z południem Wielkopolski. Gmina spełnia szereg innych funkcji, $\mathrm{z}$ których najistotniejsze to: mieszkaniowa, rolna (rolniczy charakter krajobrazu), usługowa i przemysłowa, które powiązane są $\mathrm{z}$ lokalnym rynkiem pracy.

\section{Zagospodarowanie przestrzenne, partycypacja procesu planowania przestrzennego i percepcja przestrzeni}

Pojęcie zagospodarowania przestrzennego jest wieloznaczne. Według R. Domańskiego (2006) termin ten należy rozumieć jako końcowy efekt procesów związanych $\mathrm{z}$ planowaniem przestrzennym, które $\mathrm{z}$ kolei jest elementem gospodarki przestrzennej, czyli całokształtu działań związanych z zarządzeniem użytkowanej przestrzeni. Zagospodarowanie przestrzenne to wyraz stanu 
istniejącego, jaki możemy zaobserwować w przestrzeni. Jak podaje J.J. Parysek (2006, s. 108) jest to rezultat realizacji planów zagospodarowania przestrzennego, a ściślej ,przestrzenna organizacja, struktura i funkcjonowanie terytorialnego systemu społecznego", który w tym przypadku stanowi gmina. Ankietowani oceniali stan zagospodarowania, czyli elementy widziane, odbierane w przestrzeni oraz planowanie przestrzenne, zatem proces, który do takiej kreacji przestrzeni doprowadził. Na system planowania przestrzennego w Polsce składają się dokumenty planistyczne, których stopień znajomości respondenci deklarowali. Dodatkowo w badaniu umieszczono pytania dotyczące oceny prowadzonej $\mathrm{w}$ gminie gospodarki lokalnej, czyli procesu, w którym władze przy pomocy mieszkańców oraz podmiotów zewnętrznych stymulują rozwój gospodarczy (Blakely 1989, za: Paryskiem 2001). Jednym z instrumentów wdrażania rozwoju lokalnego jest strategia rozwoju gminy.

$\mathrm{Z}$ procesem planowania przestrzennego nieodłącznie związana jest partycypacja społeczna. Pojęcie to oznacza współpracę na linii władza-mieszkańcy w trakcie przygotowywania i realizacji danej polityki. Niezwykle ważne jest, aby udział mieszkańców we współdziałaniu miał charakter czynny. Ma ona szczególne znaczenie, kiedy w podejmowaniu decyzji na różnych frontach zarządzania jednostką samorządu terytorialnego, istotną rolę odgrywa społeczeństwo demokratyczne. Uspołecznianie dotyczy również gospodarki przestrzennej i jest gwarantowane nie tylko tradycją społeczeństwa obywatelskiego, ale przede wszystkim dzięki prawu, a dokładniej Ustawie z dnia 27 marca 2003 roku o planowaniu i zagospodarowaniu przestrzennym (Dz.U., 2015, poz. 199 z późn. zm). Funkcjonujący w Polsce system planowania przestrzennego deleguje zadania związane $\mathrm{z}$ planowaniem miejscowym i formułowaniem polityki przestrzennej na najniższy szczebel administracyjny, czyli gminę. To z kolei powoduje, że pełne władztwo planistyczne przejawia się tworzeniem opracowań i dokumentów dotyczących tych zagadnień. Ustawa zakłada konieczność udziału społeczności lokalnej w procesie planowania przestrzennego, w szczególności podczas uchwalania studium uwarunkowań i kierunków zagospodarowania przestrzennego oraz miejscowych planów zagospodarowania przestrzennego. Zainteresowane podmioty (obywatele) w przypadku obydwu wyżej wymienionych dokumentów mają prawo do:

- składania wniosków,

- wglądu do projektu,

- uczestnictwa w dyskusji publicznej nad przyjętymi rozwiązaniami,

- uzyskania wyjaśnień, zgłoszenia postulatów,

- zgłoszenia uwag do wyłożonego projektu.

W pierwszym etapie prac planistycznych, społeczność lokalna jest również informowana $\mathrm{w}$ formie ogłoszenia o rozpoczęciu danej procedury. Podobnie w przypadku tworzenia strategii rozwoju gminy, które w Polsce tworzone są często przez lokalne grupy działania. Opracowywanie takiego dokumentu jest więc praktycznym przykładem inicjatywy oddolnej. 
Partycypacja społeczna odgrywa ważną rolę z uwagi na fakt mnogości podmiotów mających interes $\mathrm{w}$ tym, jak przestrzeń zostanie zagospodarowana. Istnieje jednak wyraźny dylemat $\mathrm{z}$ aktywizacją większości społeczeństwa do wnoszenia uwag i postulatów w procesie planowania przestrzennego. Problem stanowi zwłaszcza uświadomienie wagi, jaką ma głos społeczeństwa w tych działaniach. Niestety ciągle góruje przeświadczenie, że jest on nieznaczący i decyzje podejmowane są ostatecznie przez władze na danym obszarze. Jak podaje J.J. Parysek (2006) receptą na taki stan rzeczy powinna być aktywna, zachęcająca postawa rządzących $\mathrm{w}$ gminach.

Podejmując rozważanie na temat tego, jak społeczność odbiera, postrzega, ocenia, opisuje i wreszcie w jaki sposób kształtuje przestrzeń lokalną trudno nie skorzystać z doświadczeń antropologii, czyli nauki o człowieku, która mówi m.in. o jego właściwościach psychicznych i społecznych, a także o jego powiązaniach z całokształtem wytworów ludzkich (Stownik wyrazów obcych 1971, s. 22). Nieodłącznie wiąże się z tym pojęcie percepcji, którego przedmiotem jest obraz rzeczywistości z uwzględnieniem jego różnorodności. Jest to forma poznania ludzkiego, a na nią składają się doznania zmysłowe, w tym, odgrywające główną rolę, wzrokowe. Na końcową ocenę zagospodarowania przestrzennego będzie miał jednak wpływ szereg czynników, spośród których wymienić można: wiek, wykształcenie, płeć, miejsce i czas zamieszkania, wykonywany zawód, a nawet światopogląd, poszczególne cechy charakteru i doświadczenia życiowe, czy też tak trudne do zdefiniowania poczucie piękna, gust. To, jak zostanie przez danego członka społeczności lokalnej odebrana przestrzeń w jego najbliższej okolicy, jest zatem znakiem zapytania i wynikiem wpływu wielu zmiennych, które trudno przewidzieć i sklasyfikować. Jest to zjawisko widocznie zindywidualizowane, ponieważ człowiek przejawia poza funkcjonalnym, również emocjonalny stosunek do otoczenia (Wysocka 2003). Dopiero pełny wywiad byłby w stanie nakreślić, co tak naprawdę decyduje o ocenie zagospodarowania danej przestrzeni.

W swoich rozważaniach teoretycznych A. Wolski (2014) podkreśla, że w procesie percepcji przestrzeni lokalnej nie należy bagatelizować znaczenia wiedzy danego obserwatora o tym obszarze. Autor ma na myśli przede wszystkim oswajanie miejsca i socjalizację w lokalnej przestrzeni. Obserwator stanowiący jej część będzie miał z nią typowe dla danej społeczności skojarzenia, będzie znał historię kształtującą oceniane miejsce, co wreszcie istotnie wpłynie na jej odbiór. Percepcja jest zatem silnie powiązana ze świadomością, a tę kształtuje wiedza np. o procesach rządzących gospodarowaniem przestrzenią.

Nie dotarto do wyników obserwacji, które uwzględniałyby wpływ wiedzy o procesach planowania przestrzennego na odbiór przestrzeni i ocenę lokalnej polityki przestrzennej. Ten element badania stanowi zatem o wartości dodanej prowadzonej analizy i potwierdza celowość odpowiedzi na postawione w artykule pytania. 
Najważniejsze publikacje na gruncie nauk geograficznych, związanych z gospodarką przestrzenną i urbanistyką, a odwołujące się do percepcji przestrzeni powstały $\mathrm{w}$ zakresie kategorii porządkujących tę przestrzeń, czyli służących do opisu odbieranego stanu zagospodarowania (Lynch 1960).

Realizowane dotychczas prace ściśle $\mathrm{z}$ zakresu odczuwania przestrzeni odwoływały się w głównej mierze do związku między poziomem oceny stanu zagospodarowania i zmiennymi jakościowymi takimi, jak: wiek, płeć, miejsce zamieszkania itp. Obszarem badań było zazwyczaj miasto. Temat percepcji przestrzeni wsi jest w literaturze niestety marginalizowany (Tobiasz-Lis, Wójcik 2014).

B. Konecka-Szydłowska (2013) w swoich badaniach nad percepcją przestrzeni małego miasta wykorzystała metodę dyferencjału semantycznego, również w oparciu o badanie ankietowe. Respondenci oceniali poszczególne elementy stanu zagospodarowania w kontekście ładu przestrzennego. Nie skupiono się natomiast na analizie zależności między cechami badanej populacji a wynikiem oceny.

Podobne badania przeprowadzano wielokrotnie w odniesieniu do aglomeracji miejskich, np. Górnego Śląska (Libura 1990), Wielkopolski (Cichy-Pazder 2007), Kujaw (Radwańska 2007), Dolnego Śląska (Rak 2013). W ostatniej z wymienionych prac starano się skorelować wiedzę mieszkańców na temat regionu z odbiorem wizerunku danego miasta.

W tym miejscu warto również przytoczyć wyniki badań przeprowadzonych w 2008 roku wśród Polaków przez Centrum Badania Opinii Społecznej, z których wynikało, że ponad $47 \%$ ankietowanych uważało, iż główną odpowiedzialność za stan estetyki otoczenia ponoszą władze lokalne ${ }^{1}$. Około $24 \%$ badanych wskazało na odpowiedzialność urbanistów i architektów. Tylko $12 \%$ respondentów była zdania, że dbanie o posesje to zadanie właścicieli, czy też zarządców nieruchomości. W innym pytaniu dotyczącym czynników decydujących o wyborze domu zaledwie co pięćdziesiąta osoba wskazała, że jest to „wkomponowanie domu w otaczającą zabudowę”. Był to zatem czynnik klasyfikowany jako jeden z najmniej znaczących. Wynik badania wskazuje jednoznacznie, jak niewielką wiedzą i aktywnością społeczną w zakresie planowania przestrzennego wykazuje się polskie społeczeństwo.

\section{Metody}

Zastosowana technika doboru próby do badania ankietowego to metoda kuli śnieżnej, stosowana przede wszystkim $\mathrm{w}$ jakościowych badaniach $\mathrm{z}$ zakresu nauk społecznych. Polega ona na zaangażowaniu do badania uczestników

\footnotetext{
${ }^{1}$ CBOS, 2008, Zabudowa $w$ Polsce - oceny i opinie. Raport z badań ilościowych, Warszawa, http://www.cbos.pl/PL/publikacje/raporty.php (dostęp: sierpień 2014).
} 
zrekrutowanych przez innych uczestników. Metoda jest niereprezentatywna i należy do grupy prób nieprobabilistycznych (nielosowych) o nierygorystycznych zasadach doboru próby. Wadą tej metody jest to, że badacz ma nad nią małą kontrolę i poziom reprezentatywności stoi pod znakiem zapytania. Możliwość obciążenia próby wynika $\mathrm{z}$ tego, że uczestnicy mają tendencję do rekrutowania osób, które dobrze znają, a w związku z tym, biorący udział w badaniu mogą mieć zbliżone do siebie cechy. Stosunkowo nieliczna grupa respondentów jest uzasadniona $\mathrm{z}$ uwagi na:

- podstawowy charakter badania, który ma za zadanie wstępną eksplorację zjawiska i stanowi jedynie zaczątek do dyskusji nad aspektem dotychczas pomijanym w literaturze,

- jakościowy typ analizowanych zmiennych (Babbie 2004).

Rozkład próby wskazuje jednak, że stanowi ona odzwierciedlenie badanej populacji, jaką są mieszkańcy gminy Kotlin.

$\mathrm{W}$ celu odpowiedzi na postawione $\mathrm{w}$ pracy problemy badawcze związane $\mathrm{z}$ wpływem wiedzy o planowaniu przestrzennym na postrzeganie stanu zagospodarowania przestrzennego skupiono się na zagadnieniu $\mathrm{z}$ badania poświęconego ocenie polityki przestrzennej gminy Kotlin przez jej mieszkańców. Ankietę przeprowadzono od czerwca do sierpnia 2013 roku. Respondenci mieli za zadanie określić, jak żyje im się na terenie gminy Kotlin, co sądzą na temat jej atrakcyjności, jakie zauważają mocne i słabe strony tej przestrzeni. Ankieta składała się z 25 pytań, które podzielono na 3 części. Pierwsza dotyczyła związków respondentów z miejscem zamieszkania. Druga część zawierała pytania na temat relacji władz i mieszkańców oraz ich zaangażowania w rozwój przestrzenny gminy. Trzecia miała na celu ocenę wybranych elementów zagospodarowania przestrzennego gminy oraz określenie głównych problemów rozwojowych. Zagadnienia ankiety formułowano tak, aby mieszkańcy niemający do czynienia na co dzień z planowaniem przestrzennym potrafili odpowiedzieć na postawione pytania, a jednocześnie sama analiza odpowiedzi pozwalała na wyciągnięcie wniosków dotyczących polityki przestrzennej i samych respondentów.

W badaniu wzięło udział 155 pełnoletnich mieszkańców gminy Kotlin ( $2 \%$ populacji), którzy reprezentowali każdą z 12 wsi sołeckich. Zgodnie ze zgromadzonymi informacjami przewagę wśród ankietowanych stanowily kobiety (55\%). Najwięcej osób biorących udział w badaniu było w wieku 46-65 lat (37\%; por. rys. 1). Największą grupę wśród ankietowanych stanowiły osoby z wykształceniem wyższym (64 osoby) i średnim (60), łącznie 80\% próby. Zdecydowanie mniej badanych zadeklarowało wykształcenie zasadnicze zawodowe (12\%) lub podstawowe (4\%). 


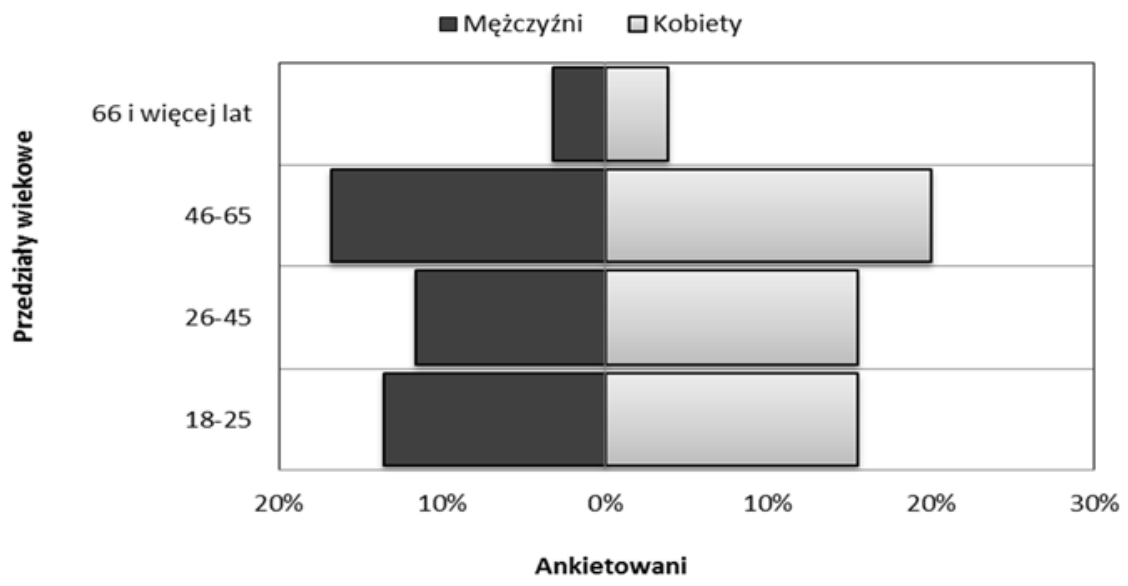

Rys. 1. Piramida płci i wieku badanej próby

Źródło: opracowanie własne na podstawie badań ankietowych

W celu rozwiązania sformułowanych problemów badawczych postawiono następujące pytania:

Czy znajomość dokumentów planistycznych i strategicznych wpływa na:

1) ocenę atrakcyjności gminy,

2) ocenę działalności władz gminy w zakresie planowania przestrzennego,

3) pozytywną ocenę zmian w zagospodarowaniu przestrzennym,

4) ocenę poszczególnych elementów zagospodarowania gminy?

Odpowiedzi na istotne dla badania pytania poddano analizie statystycznej. Wielkość populacji generalnej wynosiła 5776 mieszkańców (osoby pełnoletnie). Próba liczyła 155 osób. Podczas doboru jej liczebności, przy przyjętym poziomie ufności 90\%, błąd oszacowania wyniósł 6,5\%. Ze względu na jakościowy charakter cech, weryfikacji hipotez o niezależności zmiennych dokonano za pomocą testu niezależności chi-kwadrat.

Test niezależności chi-kwadrat (Pearsona) polega na porównywaniu ze sobą wartości obserwowanych (uzyskanych w badaniu) z wartościami oczekiwanymi (zakładanymi w sytuacji, gdy nie ma żadnego związku pomiędzy zmiennymi). Jeżeli różnica pomiędzy wartościami obserwowanymi a oczekiwanymi jest istotna statystycznie to można powiedzieć, że zachodzi relacja pomiędzy jedną zmienną a drugą. Aby wykorzystać test chi-kwadrat należy sformułować hipotezę zerową i alternatywną. Pierwsza zakłada, że badane zmienne są niezależne, natomiast druga przeciwnie - wskazuje na zależność. Postać statystyki chi-kwadrat jest następująca:

$$
\chi^{2}=\sum_{i=1}^{k} \sum_{j=1}^{r} \frac{\left(n_{i j}-\widehat{n_{l j}}\right)^{2}}{\widehat{n_{l j}}}
$$


Wartość $n_{i j}$ to liczebności zaobserwowane (empiryczne), a $\widehat{n_{l j}}$ to liczebności oczekiwane (teoretyczne). Na podstawie otrzymanych danych dwuwymiarowych można skonstruować tablicę wielodzielczą. Statystyka $\chi^{2}$ przy prawdziwości założenia hipotezy zerowej ma asymptotyczny rozkład $\chi^{2} \mathrm{z}$ :

$$
(r-1)(k-1)
$$

stopniami swobody. Zbiór krytyczny jest prawostronny, a granicą przedziału krytycznego jest wartość odczytana z tablicy rozkładu $\chi^{2}$. Gdy wartość statystyki jest większa lub równa wartości krytycznej odrzucamy hipotezę zerową głoszącą niezależność zmiennych (Sobczyk 2000).

Wnioskowanie statystyczne jest uzasadnione, jeśli liczebności oczekiwane są nie mniejsze niż 5 we wszystkich komórkach tablicy wielodzielczej. W przeciwnym wypadku łączy się wybrane klasy (co miało miejsce w przypadku przeprowadzonych na potrzeby artykułu analiz), aby uzyskać wyższe wartości przekraczające dozwolony próg (Blalock 1975, za: Kończak, Chmielińska 2013).

Ponadto $\mathrm{w}$ pracy posłużono się również prostym opisem statystycznym dotyczącym odpowiedzi na inne istotne pytania dotyczące poruszanej problematyki.

\section{Wyniki badania}

Według wyników przeprowadzonego badania ankietowego ponad $2 / 3$ respondentów była zadowolona ze swojego obecnego miejsca zamieszkania. Zainteresowanie planowanymi inwestycjami, projektami i kierunkami rozwoju gminy wyrażała połowa ankietowanych. Gminę Kotlin jako atrakcyjną do zamieszkania oceniło $51 \%$ respondentów. Zdanie takie przedstawiły przede wszystkim osoby w wieku 26-65 lat oraz długoletni mieszkańcy gminy, którzy deklarowali również zadowolenie z faktu zameldowania na tym terenie. Według respondentów atrakcyjność Kotlina jest wynikiem: dobrej komunikacji, dostępności do podstawowych usług, dużej powierzchni terenów zieleni, zadbanej, spokojnej i bezpiecznej przestrzeni, położenia $\mathrm{z}$ dala od miejskiego zgiełku oraz istnienia obiektów rekreacyjnych. Wśród odpowiedzi wyraźnie widać, że na atrakcyjność danego miejsca wpływa nie sama architektura, ale użyteczność i funkcjonalność przestrzeni (Krzyżaniak 2012).

Swoje uczestnictwo w konsultacjach społecznych potwierdziło w ankiecie zaledwie 29 osób. Niekorzystnie sytuacja kształtowała się również dla odpowiedzi udzielonych w pytaniu dotyczącym częstotliwości składania przez mieszkańców wniosków do procedur planistycznych. Takiego nigdy nie sporządziło 144 ankietowanych. Ponad połowa respondentów uważała, że osobiście nie ma wpływu na procesy zagospodarowania w gminie. Około $70 \%$ badanych 
było zdania, że udział wszystkich mieszkańców w tej kwestii jest znikomy. Spośród osób pewnych swojego braku wpływu na rozwój przestrzenny $1 / 3$ nie uczestniczyła w wyborach samorządowych w 2010 roku, zdecydowana większość $\mathrm{w}$ tej grupie nie zapoznawała się również z dokumentami planistycznymi dotyczącymi terenu gminy. Ich zdanie można zatem uznać za częściowo bezpodstawne. Jest to interesujące zjawisko wskazujące na chęć wpływu na zmianę otoczenia niepotwierdzoną żadnymi działaniami.

Ponad $2 / 3$ ankietowanych uważała, że rozwój gminy ma charakter pozytywny, co jest pewną niekonsekwencją $\mathrm{w}$ stosunku wyrażonego $\mathrm{w}$ odpowiedziach do innego pytania niezupełnego zadowolenia $\mathrm{z}$ działalności władz w zakresie gospodarki przestrzennej.

Wśród wybranych elementów zagospodarowania przestrzennego gminy zdecydowanie najlepiej ocenione zostały: poziom skomunikowania i gęstość dróg, estetyka budynków szkół, urzędu, biblioteki, GOPS i innych budynków użyteczności publicznej oraz posesji prywatnych, a także stan środowiska przyrodniczego.

Znajomość dokumentów planistycznych obowiązujących w gminie Kotlin, tj. Studium uwarunkowań i kierunków zagospodarowania przestrzennego gminy Kotlin, miejscowych planów zagospodarowania przestrzennego, Strategii rozwoju gminy Kotlin, Planu odnowy Kotlina wśród ankietowanych była znikoma (por. rys. 2).

$\square$ Ankietowani, którzy znają dokument $\quad \square$ Ankietowani, który nie znają dokumentu

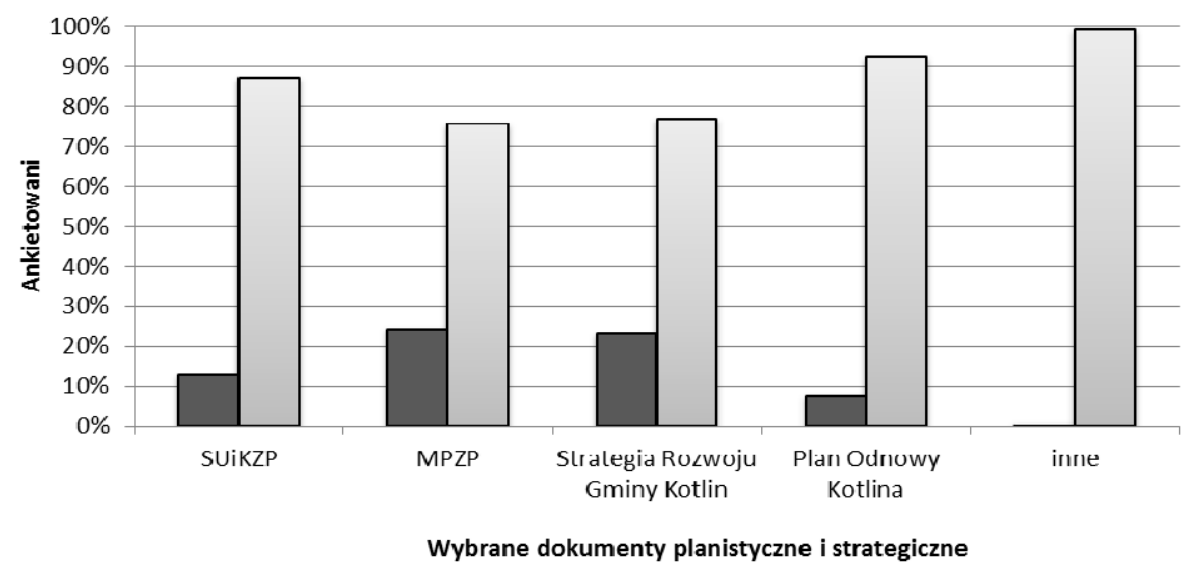

Rys. 2. Znajomość opracowań planistycznych wśród ankietowanych mieszkańców gminy Kotlin

Objaśnienia: MPZP - miejscowe plany zagospodarowania przestrzennego, SUiKZP - studium uwarunkowań i kierunków zagospodarowania przestrzennego Źródło: opracowanie własne na podstawie badań ankietowych 
Prawie 100 respondentów nie znało żadnego dokumentu, natomiast z przynajmniej jednym zapoznała się $1 / 3$ badanych. Respondenci najczęściej deklarowali znajomość miejscowych planów zagospodarowania przestrzennego $(25 \%)$ i Strategii rozwoju gminy Kotlin (23\%). Tylko 6 na 155 ankietowanych zapoznało się ze wszystkimi podanymi w pytaniu opracowaniami. Przy czym ich faktyczna znajomość nie została w żaden sposób potwierdzona. Należy również zaznaczyć, że wszystkie dokumenty planistyczne i strategiczne są łatwo dostępne w wersjach: elektronicznej w Internecie oraz papierowej w urzędzie gminy. Wyniki badania wskazują na brak związku między deklaracją mieszkańców o zainteresowaniu rozwojem gminy a faktycznym przygotowaniem merytorycznym $\mathrm{w}$ tym aspekcie i podjętymi działaniami zmierzającymi do możliwości zmiany otoczenia.

W celu odpowiedzi na postawione $\mathrm{w}$ artykule główne pytania badawcze porównano rozkłady odpowiedzi na istotne pytania przez respondentów mających lepsze lub gorsze rozeznanie w dokumentach planistycznych i prowadzonej $\mathrm{w}$ gminie polityce przestrzennej.

Zastosowany test niezależności chi-kwadrat wykazał brak zależności pomiędzy wiedzą o planowaniu przestrzennym a oceną stopnia atrakcyjności gminy Kotlin. Nie ma ona również istotnego wpływu na ocenę działalności władz w zakresie planowania przestrzennego, czy też dostrzeganie pozytywnych zmian w zagospodarowaniu przestrzennym gminy w ciągu ostatnich 10 lat. $\mathrm{W}$ tab. 1 przedstawiono wybrane przykładowe tablice dwudzielcze, na podstawie których wyliczono statystyki przy poziomie istotności $\alpha=0,05$.

Tabela 1

Tablica danych do obliczenia statystyki chi-kwadrat dla odpowiedzi na wybrane pytanie

\begin{tabular}{|l|c|c|c|}
\hline \multirow{2}{*}{$\begin{array}{c}\text { Znajomość opracowań } \\
\text { planistycznych }\end{array}$} & \multicolumn{2}{|c|}{$\begin{array}{c}\text { Czy gmina Kotlin jest atrakcyjnym } \\
\text { miejscem do zamieszkania? }\end{array}$} & \multirow{2}{*}{ Razem } \\
\cline { 2 - 3 } & Tak & Nie & \\
\hline Przynajmniej jednego & 35 & 14 & 49 \\
\hline Nieznajomość żadnego & 62 & 25 & 87 \\
\hline Razem & 97 & 39 & 136 \\
\hline \multirow{2}{*}{$\begin{array}{c}\text { Znajomość opracowań } \\
\text { planistycznych }\end{array}$} & $\begin{array}{c}\text { Jak oceniasz działalność władz } \\
\text { w zakresie zagospodarowania? }\end{array}$ & \multirow{2}{*}{ Razem } \\
\cline { 2 - 3 } & Dobrze & Źle & 40 \\
\hline Przynajmniej jednego & 17 & 23 & 47 \\
\hline Nieznajomość żadnego & 29 & 68 & 137 \\
\hline Razem & 46 & 91 & 40 \\
\hline
\end{tabular}

Źródło: opracowanie własne na podstawie badań ankietowych. 
Inaczej sytuacja kształtowała się w przypadku zależności pomiędzy znajomością dokumentów planistycznych i oceną poszczególnych elementów zagospodarowania przestrzennego. $\mathrm{W}$ kilku przypadkach wynik statystyki $\chi^{2}$ był wyraźnie wyższy od odczytów z tablicy rozkładów. Tym samym świadczyło to przeciw hipotezie o niezależności zmiennych. Dotyczy to np. oceny stanu terenów zieleni czy estetyki budynków użyteczności publicznej na terenie gminy. Na podstawie dokonanych obliczeń można stwierdzić, że znajomość opracowań planistycznych i strategicznych przy przyjętym poziomie istotności przypuszczalnie wpływa na ocenę niektórych elementów stanu zagospodarowania.

\section{Podsumowanie}

W badaniach nad percepcją przestrzeni geograficznej najczęściej kładzie się nacisk na wynik oceny, waloryzację lub też kategoryzację elementów składających się na tę przestrzeń. Zdecydowanie rzadziej analizowana jest przyczyna takich wyników tkwiąca niejednokrotnie w odmienności obserwatorów. Czerpiąc $\mathrm{z}$ dokonań nauk humanistycznych należy podjąć się również oceny zróżnicowania badanej grupy, aby w ten sposób móc w pełni dokonać rzetelnej analizy. Sposób percepcji przestrzeni, w której człowiek egzystuje jest bowiem wynikową wielu czynników. Najczęściej zalicza się do nich wiek, wykształcenie, płeć, miejsce zamieszkania, zawód, cechy osobowości, doświadczenia życiowe czy gust. Jest to zjawisko wysoce zindywidualizowane.

Jedną z istotnych cech mogących wpływać na ocenę przestrzeni danej jednostki terytorialnej i procesów w niej zachodzących jest według autora wiedza i doświadczenie $\mathrm{w}$ zakresie zagadnień dotyczących stanu zagospodarowania, a więc szeroko pojętych procedur związanych z gospodarką przestrzenną i lokalną. Wiedzę na temat kierunków rozwoju gminy społeczeństwo może czerpać biorąc aktywnie udział $\mathrm{w}$ działaniach planistycznych bądź też zapoznając się $z$ dokumentacją projektową. Działania te pozwalają na lepszy ogląd i zrozumienie zjawisk zachodzących w najbliższym otoczeniu.

Głównym celem niniejszego artykułu było przedstawienie wyników analiz i próba rozwiązania problemów badawczych sformułowanych na wstępie, a dotyczących bezpośrednio wpływu znajomości opracowań planistycznych i strategicznych na ocenę atrakcyjności przestrzeni gminy, elementów zagospodarowania składających się na nią czy też decyzji władz gminy w zakresie jej rozwoju. Aby odpowiedzieć na postawione pytania badawcze, przeprowadzono ankietę wśród mieszkańców gminy wiejskiej Kotlin. Wyniki sugerują, że mieszkańcy interesują się rozwojem i gospodarką przestrzenną gminy, choć w małym stopniu znają strategiczne opracowania planistyczne dotyczące tych zagadnień. Nie biorą niestety udziału w procesach zagospodarowania. 
Respondenci średnio oceniają pracę władz w tym zakresie, jednocześnie zauważają wiele pozytywnych zmian $\mathrm{w}$ zagospodarowaniu gminy $\mathrm{w}$ latach 2003-2013.

Przeprowadzone analizy statystyczne $\mathrm{z}$ wykorzystaniem testu niezależności chi-kwadrat nie wykazały związku między znajomością opracowań planistycznych a oceną stopnia atrakcyjności gminy lub oceną działalności władz w zakresie gospodarki przestrzennej. Wystąpiła natomiast w wynikach wyraźnie widoczna zależność między oceną niektórych elementów zagospodarowania a wiedzą i doświadczeniem $\mathrm{w}$ aspekcie planowania przestrzennego.

Przeprowadzone badania i ich wyniki skłaniają do dalszych prac w tym zakresie, które pozwoliłyby, poza widoczną zależnością, wskazać także jej kierunek i siłę. Ponadto zachętą powinien być fakt, że tereny wiejskie są zdecydowanie rzadziej poddawane badaniom oceny percepcji przestrzeni w stosunku do miast, co sugeruje konieczność rozszerzenia i pogłębienia tego typu badań.

\section{LITERATURA}

Babbie E., 2004, Badania spoleczne w praktyce, PWN, Warszawa.

Blakely E.J., 1989, Planning local economic development. Theory and practice, Sage Library and Social Research, 168, London.

Blalock H.M., 1975, Statystyka dla socjologów, PWN, Warszawa.

CBOS, 2008, Zabudowa w Polsce - oceny i opinie. Raport z badań ilościowych, Warszawa.

Cichy-Pazder E., 2007, Atrakcyjność miasta metropolitalnego. Wyznaczniki percepcyjne i behawioralne, [w:] Madurowicz M. (red.), Percepcja wspótczesnej przestrzeni miejskiej, Wydawnictwo Wydziału Geografii Studiów Regionalnych Uniwersytetu Warszawskiego, Warszawa.

Domański R., 2006, Gospodarka przestrzenna. Podstawy teoretyczne, Wydawnictwo Naukowe PWN, Warszawa.

Konecka-Szydłowska B., 2013, Percepcja przestrzeni małego miasta na przykładzie Gościna, „Acta Universitatis Lodziensis”, Folia Geographica Socio-Oeconomica, 15, Łódź, s. 193-207.

Kończak G., Chmielińska M., 2013, Zastosowanie metod symulacyjnych w analizie wielowymiarowych tablic wielodzielczych, „Studia Ekonomiczne”, 133, Uniwersytet Ekonomiczny w Katowicach, s. 107-118.

Krzyżaniak J.M., 2012, Dobre praktyki zagospodarowania przestrzeni wiejskiej na przykładzie laureatów konkursu „Przyjazna wieś”, [w:] Kurowska K., Gwiaździńska-Goraj M. (red.), Planowanie rozwoju przestrzeni wiejskiej, „Studia Obszarów Wiejskich", 29, Warszawa, s. 247-263.

Libura H., 1990, Percepcja przestrzeni miejskiej, Wydawnictwa Programu CPBP 09.8 „Rozwój regionalny - rozwój lokalny - samorząd terytorialny”, Warszawa.

Lynch K., 1960, The image of the city, MIT Press, Cambridge. 
Parysek J.J., 2001, Podstawy gospodarki lokalnej, Wydawnictwo Naukowe UAM, Poznań.

Parysek J.J., 2006, Wprowadzenie do gospodarki przestrzennej. Wybrane aspekty przestrzenne, Wydawnictwo Naukowe UAM, Poznań.

Parysek J.J., 2010, Gospodarka przestrzenna i rola partycypacji społecznej $w$ procesie planowania przestrzennego, [w:] Ratajczak W., Stachowiak K. (red.), Gospodarka przestrzenna społeczeństwu, Bogucki Wydawnictwo Naukowe, Poznań.

Radwańska M., 2007, Percepcja przestrzeni miejskiej - przykład miasta Torunia, [w:] Madurowicz M. (red.), Percepcja współczesnej przestrzeni miejskiej, Wydawnictwo Wydziału Geografii Studiów Regionalnych Uniwersytetu Warszawskiego, Warszawa.

Rak G., 2013, Percepcja przestrzeni regionalnej, Instytut Turystyki i Rekreacji, Politechnika Opolska, Wrocław.

Słownik wyrazów obcych, 1971, PWN, Warszawa.

Sobczyk M., 2000, Statystyka. Podstawy teoretyczne. Przyklady - zadania, Wydawnictwo UMCS, Lublin.

Tobiasz-Lis P., Wójcik M., 2014, Wyobrażenia przestrzenne mieszkańców wsi. Wykorzystanie metody odręcznych szkiców, [w:] Wójcik M. (red.), Regionalny wymiar przemian polskiej wsi - aspekty społeczne i środowiskowe, „Studia Obszarów Wiejskich", 35, Warszawa, s. 29-43.

Wolski A., 2014, Percepcja przestrzeni w społeczności lokalnej, „Prace Komisji Krajobrazu Kulturowego", 24, Katowice, s. 77-86.

Wysocka E., 2003, Wpływ społeczeństwa informacyjnego na zagospodarowanie przestrzenne, Instytut Gospodarki Przestrzennej i Mieszkalnictwa, Warszawa.

\title{
SPATIAL DEVELOPMENT OF KOTLIN RURAL COMMUNITY IN THE MINDS OF ITS INHABITANTS
}

\begin{abstract}
This article is about the spatial development of Kotlin community in the minds of its inhabitants. The main goal is an evaluation of the impact of the knowledge and experience of the local community on the perception of spatial planning its development status. In this study, using a survey and chi-square test to research knowledge of planning studies among residents, feeling their space, their satisfaction with the state of spatial policy in Kotlin community and the impact of society on the development.
\end{abstract}

Key words: spatial development, spatial planning, Kotlin community.

Mgr Bartosz Wojtyra Zakład Gospodarki Żywnościowej i Wsi Instytut Geografii Społeczno-Ekonomicznej i Gospodarki Przestrzennej Wydział Nauk Geograficznych i Geologicznych Uniwersytet im. Adama Mickiewicza w Poznaniu 